\title{
PENGEMBANGAN LKS BERBASIS PENDEKATAN CONTEXTUAL TEACHING AND LEARNING (CTL) UNTUK SISWA SMP
}

\author{
Pitriani \\ Universitas Tamansiswa Palembang \\ pitriani@unitaspalembang.ac.id
}

\begin{abstract}
Abstrak: Penelitian ini bertujuan untuk (1) menghasilkan LKS Berbasis Pendekatan Contextual Teaching and Learning (CTL) materi prisma dan limas yang valid, praktis, dan mempunyai efek potensial terhadap hasil belajar siswa, serta menjelaskan proses pengembangannya, (2) mendeskripsikan karakteristik LKS Berbasis CTL materi prisma dan limas. Penelitian ini merupakan Development Research tipe Formative Evaluation. Dalam mengembangkan LKS, peneliti melalui tahap preliminary dan protityping dengan alur formative evalution. Pada tahap protityping melibatkan siswa kelas VIII salah satu SMP negeri di Palembang. Teknik pengumpulan data yang digunakan adalah dokumentasi, walk through, dan hasil tes. Penelitian ini menghasilkan LKS Berbasis CTL materi prisma dan limas yang valid dan praktis, dan mempunyai efek potensial terhadap hasil belajar siswa. Kevalidan LKS ditinjau dari kesesuaian dengan kurikulum dan hasil validasi pakar serta uji prototipe. Efek potensial dari LKS ini terlihat dari kemampuan siswa menentukan kedudukan, jarak dan sudut unsur-unsur bangun ruang. Hasil evaluasi belajar menunjukkan bahwa 89,5 \% siswa tuntas dengan KKM 80. Dari hasil pengamatan secara umum selama proses pembelajaran siswa memiliki inisiatif dan antusias dalam belajar serta memanfaatkan sumber-sumber belajar.
\end{abstract}

Kata Kunci: LKS; CTL; prisma; limas.

\section{PENDAHULUAN}

Pembelajaran merupakan suatu proses transfer informasi yang melibatkan aspek-aspek utama dalam pembelajaran, yaitu penyampai informasi, penerima informasi, dan informasi yang disampaikan. Begitu pun dengan pembelajaran matematika, di mana yang berperan sebagai penyampai informasi adalah guru, penerima informasi adalah siswa, dan informasi yang diterima adalah matematika itu sendiri. Hal tersebut senada dengan apa yang diutarakan oleh Suryadi (2010) bahwa pembelajaran matematika melibatkan tiga aspek utama yaitu guru, siswa, dan matematika. Antara ketiga aspek tersebut memiliki keterkaitan satu sama lain yang mempengaruhi jalannya suatu pembelajaran.

Pembelajaran matematika pada siswa sampai saat ini umumnya guru hanya menyampaikan informasi kepada siswa. Proses tersebut dimulai dari guru menyampaikan materi pembelajaran dan dilanjutkan dengan guru mendemonstrasikan prosedur penyelesaian dari contoh soal. Dalam hal ini, siswa tidak banyak berpartisipasi aktif dalam kegiatan pembelajaran di kelas serta siswa hanya meniru apa yang dicontohkan oleh guru. Seperti yang diungkapkan 
oleh Silver (Turmudi, 2010) bahwa pada umumnya dalam pembelajaran matematika, para siswa memperhatikan bagaimana gurunya mendemonstrasikan penyelesaian soal-soal matematika di papan tulis dan siswa hanya meniru apa yang telah dituliskan oleh gurunya.

Kebiasaan siswa yang lebih sering hanya meniru apa yang dituliskan oleh gurunya akan menjadi suatu masalah yang besar saat siswa tersebut dihadapkan pada permasalahan yang belum pernah dicontohkan oleh gurunya. Kemungkinan besar siswa tidak akan mampu menyelesaikan permasalahan tersebut. Salah satu penyebab timbulnya hal tersebut, yaitu siswa belum memaknai proses pembelajaran yang terjadi. Hal tersebut tidak sejalan dengan apa yang dikemukakan Ausubel (Dahar, 1996) yaitu proses pembelajaran seharusnya menerapkan teori belajar bermakna yang artinya belajar dengan memulai tahapan mengetahui, memahami, mengaplikasikan, dan memilikinya.

Kurangnya kebermaknaan proses pembelajaran di Indonesia dapat berpengaruh pada hasil belajar siswa dan berujung pada rendahnya kualitas yang dicapai dalam pendidikan di Indonesia, khususnya mata pelajaran matematika. Di sisi lain, dalam standar isi untuk satuan pendidikan dasar dan menengah pemecahan masalah merupakan fokus dalam pembelajaran matematika yang mencakup masalah tertutup dengan solusi tunggal, masalah terbuka dengan solusi tidak tunggal, dan masalah dengan berbagai cara penyelesaian. Selanjutnya, dalam Standar Kompetensi Dasar dan Kompetensi Dasar matematika disusun untuk mengembangkan kemampuan menggunakan matematika dalam pemecahan masalah dan mengkomunikasikan idea tau gagasan dengan menggunakan simbol, tabel, diagram, dan media lain (BSNP, 2006). Pemerintah menjadikan kemampuan pemecahan masalah sebagai fokus dalam proses pembelajaran matematika tidak membuat kemampuan pemecahan masalah siswa Indonesia menjadi lebih unggul dibandingkan dengan siswa negara lain.

Salah satu hal yang mempengaruhi rendahnya kemampuan pemecahan matematis siswa ialah pemahaman siswa terhadap konsep yang diajarkan guru. Sedangkan pemahaman siswa tersebut dipengaruhi oleh bahan ajar yang digunakan yang mayoritas belum memadai. Di lapangan, banyak dijumpai sekolah-sekolah di kota Palembang yang hanya mengandalkan buku yang disubsidi oleh pemerintah. Buku-buku tersebut dipinjamkan dari pihak sekolah kepada siswa dalam masa satu semester. Selain itu, siswa tidak diberikan rujukan lain (misalkan LKS) sebagai sumber pembelajaran. Siswa hanya mengandalkan catatan yang diberikan oleh guru mata pelajaran. Sedangkan untuk latihan soal-soal, guru hanya memberikan soal yang ada di buku paket. Guru tidak memberikan bahan ajar dari 
sumber lain. Oleh karena itu, guru dirasa perlu untuk melakukan inovasi pembelajaran dalam hal pemberian bahan ajar yang dapat meningkatkan kemampuan pemecahan masalah siswa.

Matematika yang diajarkan di sekolah terdiri atas geometri, aljabar, peluang, statistik, kalkulus, dan trigonometri. Namun dalam mempelajari geometri siswa terkadang mengalami kesulitan ketika mempelajari objek yang bersifat abstrak, mengingat siswa masih dalam tahap belajar realistik. Salah satu usaha agar siswa memahami materi geometri ialah membantu siswa dalam membawa objek geometri ke dalam dunia nyata dengan melibatkan siswa menemukan konsep geometri itu. Dengan demikian proses pembelajaran berlangsung alamiah bukan transfer pengetahuan dari guru ke siswa. Upaya melibatkan siswa menemukan konsep dapat dilakukan dengan memanfaatkan bantuan perangkat pembelajaran, yaitu LKS. LKS akan menuntut siswa harus "berbuat" matematika.

Menurut Amin Suyitno (Lestari, 2006:18) LKS adalah media cetak yang berupa lembaran kertas yang berisi informasi dan soal/pertanyaan yang harus dijawab siswa. LKS ini sangat baik dipakai untuk menggalakkan keterlibatan siswa dalam belajar. LKS berbasis Pendekatan Contextual Teaching and Learning (CTL) ialah LKS yang berisi informasi dan soal-soal yang sesuai dengan kehidupan sehari-hari siswa serta memuat 7 komponen
CTL. Sehingga pembelajaran akan jauh lebih bermakna dan melekat sebab konsepnya ditemukan sendiri dan aplikasinya erat dengan kehidupan sehari-hari serta dapat meningkatkan pencapaian kompetensi siswa.

Pembelajaran

Contextual

Teaching and Learning (CTL) adalah konsep belajar yang membantu guru mengaitkan antara materi yang diajarkannya dari situasi dunia nyata siswa serta mendorong siswa membuat hubungan antara pengetahuan yang dimilikinya dan penerapannya dalam kehidupan sehari-hari (Shoimin, 2014 \& Riyanto, 2010). Pembelajaran ini melibatkan 7 komponen utama pembelajaran, yakni: konstruktivisme (constructivism), bertanya (questioning), inkuiri (inquiry), masyarakat belajar (learning community), pemodelan (modeling), refleksi (reflection) dan penilaian autentik (authentic assessment) (Trianto, 2007:103).

Kesulitan-kesulitan yang dialami siswa perlu mendapatkan bantuan guru dengan harapan hasil belajar siswa dapat optimal. Berdasarkan kesulitan-kesulitan tersebut, guru yang mempunyai peran sebagai fasilitator, seharusnya dapat memfasilitasi siswa dalam mempersiapkan suatu bahan ajar berupa LKS yang sesuai dengan kebutuhan siswa serta konsep dalam matematika yang sedang dikaji. Penyusunan dan pengembangan LKS ini diharapkan dapat menciptakan sebuah situasi yang menjadi titik awal terjadinya proses pembelajaran 
dengan melibatkan aktivitas siswa di dalamnya sehingga terjadi pembelajaran multi arah (guru-materisiswa).

Berdasarkan kondisi yang telah dipaparkan sebelumnya, diperlukan perhatian, pengkajian, dan pembahasan secara lebih mendalam mengenai permasalahan yang dihadapi siswa serta solusi yang dapat diberikan. Perhatian terhadap hubungan guru-siswa-materi dalam menciptakan situasi belajar yang kondusif untuk terjadinya proses berpikir menjadi hal utama untuk dilakukan penelitian. Oleh karena itu, peneliti mengembangkan LKS atau bahan ajar materi bangun ruang prisma dan limas untuk meningkatkan hasil belajar siswa.

\section{TINJAUAN TEORETIS}

\section{Lembar Kegiatan Siswa (LKS)}

Lembar kegiatan siswa (student work sheet) adalah lembaranlembaran berisi tugas yang harus dikerjakan oleh peserta didik (Inra, 2010). Lembar kegiatan siswa memuat diantaranya judul, kompetensi dasar yang akan dicapai, waktu penyelesaian, peralatan/bahan yang diperlukan untuk menyelesaikan tugas, informasi singkat, langkah kerja, tugas yang harus dilakukan, dan laporan yang harus dikerjakan. Keuntungan adanya lembar kegiatan adalah bagi guru, memudahkan guru dalam melaksanakan pembelajaran, bagi siswa akan belajar secara mandiri dan belajar memahami dan menjalankan suatu tugas tertulis. Ada dua macam lembar kegiatan siswa (LKS) yang dikembangkan dalam pembelajaran di sekolah (Widiyanto, 2007).

a. Lembar Kegiatan Siswa Tak Berstruktur

Lembar kegiatan siswa tak berstruktur adalah lembaran yang berisi sarana untuk materi pelajaran, sebagai alat bantu kegiatan peserta didik yang dipakai untuk menyampaikan pelajaran. LKS merupakan alat bantu mengajar yang dapat dipakai untuk mempercepat pembelajaran, memberi dorongan belajar pada tiap individu, berisi sedikit petunjuk, tertulis atau lisan untuk mengarahkan kerja pada peserta didik.

b. Lembar Kegiatan Siswa Berstruktur

Lembar kegiatan siswa berstruktur memuat informasi, contoh dan tugas-tugas. LKS ini dirancang untuk membimbing peserta didik dalam satu program kerja atau mata pelajaran, dengan sedikit atau sama sekali tanpa bantuan pembimbing untuk mencapai sasaran pembelajaran. Pada LKS telah disusun petunjuk dan pengarahannya, LKS ini tidak dapat menggantikan peran guru dalam kelas. Guru tetap mengawasi kelas, memberi semangat dan dorongan belajar dan memberi bimbingan pada setiap siswa.

Dalam menyiapkan lembar kegiatan siswa dapat dilakukan dengan langkah-langkah sebagai berikut (Inra, 2010).

a. Analisis kurikulum 
Analisis kurikulum dimaksudkan untuk menentukan materi-materi mana yang memerlukan bahan ajar LKS. Biasanya dalam menentukan materi dianalisis dengan cara melihat materi pokok dan pengalaman belajar dari materi yang akan diajarkan, kemudian kompetensi yang harus dimiliki oleh siswa.

b. Menyusun peta kebutuhan LKS

Peta kebutuhan LKS sangat diperlukan guna mengetahui jumlah LKS yang harus ditulis dan sekuensi atau urutan LKSnya juga dapat dilihat. Sekuensi LKS ini sangat diperlukan dalam menentukan prioritas penulisan. Diawali dengan analisis kurikulum dan analisis sumber belajar.

c. Menentukan judul-judul LKS

Judul LKS ditentukan atas dasar kompetensi-kompetensi dasar, materi-materi pokok atau pengalaman belajar yang terdapat dalam kurikulum. Satu kompetensi dasar dapat dijadikan sebagai judul LKS apabila kompetensi itu tidak terlalu besar, sedangkan besarnya kompetesnsi dasar dapat dideteksi antara lain dengan cara apabila diuraikan ke dalam materi pokok (MP) mendapatkan maksimal 4 MP, maka kompetensi itu telah dapat dijadikan sebagai satu judul LKS. Namun apabila diuraikan menjadi lebih dari 4 materi pokok, maka perlu dipikirkan kembali apakah perlu dipecah misalnya menjadi 2 judul LKS. d. Penulisan LKS

Materi LKS sangat tergantung pada kompetensi dasar yang akan dicapai. Rumusan kompetensi dasar pada LKS langsung diturunkan dari buku Kurikulum Tingkat Satuan Pendidikan. Materi LKS dapat berupa informasi pendukung, yaitu gambaran umum atau ruang lingkup substansi yang akan dipelajari. Materi dapat diambil dari berbagai sumber seperti buku, majalah, internet, jurnal hasil penelitian. Agar pemahaman siswa terhadap materi lebih kuat, maka dapat saja dalam LKS ditunjukkan referensi yang digunakan agar siswa membaca lebih jauh tentang materi itu. Tugas-tugas harus ditulis secara jelas guna mengurangi pertanyaan dari siswa tentang hal-hal yang seharusnya siswa dapat melakukannya, misalnya tentang tugas diskusi. Di dalam LKS yang akan digunakan pada penelitian ini adalah LKS yang isinya tentang pokok bahasan bangun ruang sisi datar (prisma dan limas).

Dalam menyelesaikan LKS yang diberikan, apabila siswa mengalami kesulitan, guru harus memberikan beberapa intervensi sehingga siswa dapat menyelesaikan LKS tersebut. Menurut Mulyana (2008) bentuk intervensi yang mungkin diberikan dalam proses pembelajaran adalah bentuk intervensi konvergen dan bentuk intervensi divergen. Bentuk intervensi 
konvergen adalah bentuk intervensi yang dilakukan guru dengan cara memberikan pertanyaan investigasi yang bersifat tertutup dan mengarah pada penyelesaian masalah. Sementara bentuk intervensi divergen adalah bentuk intervensi yang dilakukan guru dengan cara memberikan pertanyaan investigasi yang bersifat terbuka dan mengarah pada penyelesaian masalah.

\section{Pendekatan Contextual Teaching and Learning (CTL)}

Pendekatan adalah suatu jalan, cara, atau kebijaksanaan yang ditempuh oleh guru atau siswa dalam pencapaian tujuan pengajaran apabila kita melihatnya dari sudut bagaimana proses pengajaran atau materi pengajaran itu dikelola (Dirjen Dikdasmen, 2004:3). Pendekatan Contextual Teaching and Learning (CTL) adalah konsep belajar yang membantu guru mengkaitkan antara materi yang diajarkannya dengan situasi dunia nyata siswa dan mendorong siswa membuat hubungan antara pengetahuan yang dimilikinya dengan penerapannya dalam kehidupan mereka sehari-hari, dengan melibatkan 7 komponen utama pembelajaran kontekstual, yakni: konstruktivisme (constructivism), bertanya (questioning), inkuiri (inquiry), masyarakat belajar (learning community), pemodelan (modeling), refleksi (reflection) dan penilaian autentik (authentic assessment) (Trianto, 2007:103).

Menurut Elaine B. Johnson (2006:57), Contextual Teaching and Learning adalah sebuah sistem yang merangsang otak untuk menyusun pola-pola yang mewujudkan makna. CTL adalah suatu sistem pengajaran yang cocok dengan otak yang menghasilkan makna dengan menghubungkan muatan akademis dengan konteks dari kehidupan sehari-hari siswa. Jadi, pendekatan Contextual Teaching and Learning (CTL) adalah konsep belajar atau pendekatan yang mempunyai 7 komponen dan menghubungkan dengan kehidupan siswa sehari-hari sehingga mudah dipahami.

\section{Komponen-Komponen Contextual Teaching and Learning}

Dirjen Dikdasmen (2004:35)

menyebutkan pendekatan CTL menerapkan tujuh komponen, yaitu konstruktivisme (constructivism), bertanya (questioning), inkuiri (inquiry), masyarakat belajar (learning community), pemodelan (modeling), refleksi (reflection) dan penilaian autentik (authentic assessment).

\section{1) Konstruktivisme \\ (Constructivisme)}

Konstruktivisme merupakan landasan berpikir yang digunakan dalam pembelajaran kontekstual, yaitu pengetahuan dibangun oleh manusia sedikit demi sedikit yang hasilnya diperluas melalui konteks yang terbatas dan tidak dalam waktu yang singkat. Dengan dasar itu, pembelajaran harus dikemas menjadi proses mengkonstruksi 'bukan' menerima pengetahuan. Dalam proses pembelajaran, siswa membangun sendiri pengetahuan mereka melalui keterlibatan aktif dalam proses belajar 
mengajar. Siswa menjadi pusat kegiatan, bukan guru. Dalam pandangan konstruktivis, strategi memperoleh lebih diutamakan dibandingkan seberapa banyak siswa memperoleh dan mengingat pengetahuan, bukan melihat pada hasil pembelajarannya melainkan prosesnya. Adapun tugas guru adalah memfasilitasi proses tersebut dengan :
a. menjadikan
pengetahuan

bermakna dan relevan bagi siswa,

b. memberi kesempatan siswa menemukan dan menerapkan idenya sendiri, dan

c. menyadarkan siswa agar menerapkan strategi mereka sendiri dalam belajar.

(Trianto, 2007:109)

\section{2) Inkuiri (Inquiry)}

Inkuiri merupakan bagian inti dari kegiatan pembelajaran berbasis Pendekatan CTL. Pengetahuan dan keterampilan yang diperoleh siswa diharapkan bukan hasil mengingat seperangkat fakta-fakta, tetapi hasil dari menemukan sendiri. Guru harus selalu merancang kegiatan yang merujuk pada kegiatan menemukan, apapun materi yang diajarkan. Siklus inkuiri meliputi tahapan:

(1) observasi (observation),

(2) bertanya (questioning),

(3) mengajukan dugaan (hypothesis),

(4) mengumpulkan data (data gathering),

(5) penyimpulan (conclusion).

Langkah-langkah

kegiatan menemukan (inkuiri) meliputi:

(1) merumuskan masalah (dalam mata pelajaran apapun);

(2) mengamati atau melakukan observasi;
(3) menganalisis dan menyajikan hasil dalam tulisan, gambar, laporan, bagan, tabel, dan karya lainnya;

(4) mengkomunikasikan atau menyajikan hasil karya pada pembaca, teman sekelas, guru atau audien yang lain.

(Trianto, 2007:109-110)

3) Bertanya (Questioning)

Questioning (bertanya)

merupakan strategi utama pembelajaran yang berbasis CTL. Bertanya dalam pembelajaran dipandang sebagai kegiatan guru untuk mendorong, membimbing, dan menilai kemampuan berpikir siswa. Untuk bisa berhasil, menurut Elaine B.Johnson (2006:159) siswa yang mandiri haruslah bisa mengajukan pertanyaan yang menarik. Ketakjuban adalah cikal bakal kreativitas.

Bagi siswa, kegiatan bertanya merupakan bagian penting dalam melaksanakan pembelajaran yang berbasis inkuiri, yaitu menggali informasi, mengkonfirmasikan apa yang sudah diketahui, dan mengarahkan perhatian pada aspek yang belum diketahuinya. Dalam sebuah pembelajaran yang produktif, kegiatan bertanya berguna untuk

(1) menggali informasi, baik administrasi maupun akademis;

(2) mengecek pemahaman siswa;

(3) membangkitkan respon kepada siswa;

(4) mengetahui sejauh mana keingintahuan siswa;

(5) mengetahui hal-hal yang sudah diketahui siswa; 
(6) memfokuskan perhatian siswa pada sesuatu yang dikehendaki guru;

(7) untuk membangkitkan lebih banyak lagi pertanyaan dari siswa; dan

(8) untuk menyegarkan kembali pengetahuan siswa.

(Trianto, 2007:110)

Questioning dapat diterapkan antara siswa dengan siswa, antara guru dengan siswa, antara siswa dengan guru, antara siswa dengan orang lain yang didatangkan ke kelas, dan sebagainya. Aktivitas bertanya juga ditemukan ketika siswa berdiskusi, bekerja dalam kelompok, ketika menemui kesulitan, ketika mengamati, dan sebagainya.

\section{4) Masyarakat Belajar (Learning \\ Community)}

Konsep Learning Community menyarankan agar hasil pembelajaran diperoleh dari kerja sama dengan orang lain. Hasil belajar diperoleh dari sharing antar teman, antar kelompok, dan antar yang tahu ke yang belum tahu. Siswa seyogianya dibiasakan saling belajar dari dan dalam kelompok untuk berbagi pengetahuan dan menentukan fokus belajar. Dalam setiap kolaborasi selalu ada siswa yang menonjol dibanding koleganya. Siswa ini dapat dijadikan fasilisator dalam kelompoknya (Johnson, 2006:22).

Oleh karena itu, dalam kelas CTL disarankan selalu melaksanakan pembelajaran dalam kelompokkelompok belajar yang heterogen. Masyarakat belajar bisa terjadi apabila ada proses komunikasi dua arah. Hal ini bisa terjadi apabila tidak ada pihak yang merasa segan untuk bertanya, tidak ada pihak yang merasa paling tahu, dan semua pihak mau saling mendengarkan. Setiap pihak harus merasa bahwa setiap orang memiliki pengetahuan, pengalaman, atau keterampilan yang berbeda yang perlu dipelajari.

\section{5) Pemodelan (Modeling)}

Di dalam CTL harus selalu ada model yang bisa ditiru oleh siswa sebelum mereka melakukan suatu kegiatan atau menemukan sesuatu. Model itu bisa berupa cara melakukan sesuatu kegiatan. Guru bukan satusatunya model pada pembelajaran CTL. Model dapat dirancang dengan melibatkan siswa. Seseorang bisa ditunjuk untuk memodelkan sesuatu berdasarkan pengalaman yang diketahuinya. Model dapat juga didatangkan dari luar sesuai dengan materi yang diajarkan (Trianto, 2007:113).

Pemodelan pada dasarnya membahaskan gagasan apa yang dipikirkan, mendemonstrasikan bagaimana guru menginginkan para siswanya untuk belajar dan melakukan apa yang diinginkan guru agar siswa-siswanya melakukan. Pemodelan dapat berbentuk demonstrasi, pemberian contoh tentang konsep atau aktivitas belajar oleh guru atau siswa.

\section{6) Refleksi (Reflection)}

Refleksi adalah cara berfikir tentang apa yang baru dipelajari atau berpikir ke belakang tentang apa-apa yang sudah dikerjakan. Siswa mengendapkan apa yang baru dipelajarinya sebagai struktur pengetahuan yang baru yang 
merupakan pengayaan atau revisi dari pengetahuan sebelumnya. Refleksi merupakan respon terhadap kejadian, aktivitas, atau pengetahuan yang baru diterima.

Pengetahuan yang bermakna diperoleh dari proses. Pengetahuan yang dimiliki siswa diperluas melalui konteks pembelajaran, yang kemudian diperluas sedikit demi sedikit. Guru atau orang dewasa membantu siswa membuat hubunganhubungan antara pengetahuan yang dimiliki sebelumnya dengan pengetahuan yang baru.

Pada akhir pembelajaran, guru menyisakan waktu sejenak agar siswa melakukan refleksi. Realisasinya berupa:

(1) pernyataan langsung tentang apaapa yang diperolehnya hari itu;

(2) catatan atau jurnal di buku siswa;

(3) kesan dan saran siswa mengenai pembelajaran itu;

(4) diskusi;

(5) hasil karya (Trianto, 2007:113).

7) Penilaian Autentik (Authentic Assessment)

Penilaian adalah proses pengumpulan berbagai data yang bisa memberikan gambaran perkembangan siswa. Apabila data yang dikumpulkan guru mengidentifikasikan bahwa siswa mengalami kemacetan belajar, maka guru segera mengambil tindakan yang tepat agar siswa terbebas dari kemacetan belajar. Karena gambaran tentang kemajuan belajar itu diperlukan di sepanjang proses pembelajaran, maka assessment tidak dilakukan di akhir periode pembelajaran seperti pada kegiatan $\begin{array}{lrr}\text { evaluasi } & \text { hasil } & \text { belajar } \\ \text { (Ebta/Ebtanas/US/UN), } & \text { tetapi }\end{array}$ dilakukan bersama secara integral tidak terpisahkan dari kegiatan pembelajaran. Data yang dikumpulkan melalui kegiatan penilaian bukanlah untuk mencari informasi tentang belajar siswa. Pembelajaran yang benar ditekankan pada upaya membantu siswa agar mampu mempelajari (learning how to learn) bukan ditekankan pada diperolehnya sebanyak mungkin informasi di akhir periode pembelajaran.

Adapun karakterisitik penilaian autentik menurut Trianto (2007:115) yaitu:

(1) dilaksanakan selama dan sesudah proses pembelajaran berlangsung

(2) bisa digunakan untuk formatif maupun sumatif

(3) yang diukur keterampilan dan performansi bukan mengingat fakta

(4) berkesinambungan

(5) terintegrasi

(6) dapat digunakan sebagai feed back.

Dalam CTL yang dapat digunakan sebagai dasar menilai prestasi siswa, antara lain: proyek/kegiatan dan laporannya, PR (pekerjaan rumah), kuis, karya siswa, presentasi atau penampilan siswa, demonstrasi, laporan, jurnal, hasil tes tulis, dan karya tulis.

METODOLOGI PENELITIAN

Penelitian ini merupakan

Development Research tipe Formative Evaluation dengan menggunakan teknik analisis data 
deskriptif kualitatif dan kuantitatif. Penelitian pengembangan menurut Seel \& Richey, Akker \& Plomp dalam Hadi (2002:107) adalah suatu pengkajian sistematis terhadap pendesainan, pengembangan dan pengevaluasian program proses dan produk pembelajaran yang harus memenuhi kriteria validitas, kepraktisan, dan efektivitas. Sedangkan formative evaluation menurut Akker (1999:6) adalah suatu kegiatan penelitian yang dilakukan selama pengembangan seluruh proses intervensi tertentu, yang bertujuan untuk mengoptimalkan kualitas intervensi serta prinsip-prinsip pengujian suatu desain.

Penelitian ini bertujuan untuk mengembangkan LKS dengan mengikuti dua tahap utama development research yaitu tahap preliminary study (tahap persiapan dan pendesainan) dan formative evaluation (tahap evaluasi dan revisi). Teknik pengumpulan data yang digunakan dalam penelitian ini terdiri dari walk through, observasi, dokumentasi, dan tes. Teknik-teknik tersebut digunakan untuk mengetahui keefektifan, keefisienan dan kepraktisan LKS yang dikembangkan (Tessmer, 1993:21). Walk through dilakukan peneliti pada saat uji pakar dengan cara mencatat semua komentar yang disampaikan oleh pakar sebagai bahan untuk melakukan revisi. Observasi digunakan untuk mengamati proses pembelajaran siswa ketika menggunakan LKS yang diberikan dalam one to one, small group, dan field test untuk mengetahui kepraktisan LKS.
Dokumentasi dilakukan mulai tahap desain, self evaluation, one to one, small group dan field test. Tes digunakan untuk memperoleh data tentang keefektifan atau efek potensial setelah mengikuti kegiatan pembelajaran dengan LKS Berbasis Pendekatan CTL untuk materi prisma dan limas.

Pengolahan data-data yang diperoleh dalam penelitian ini menggunakan teknik analisis deskriptif kualitatif dan kuantitatif. Analisis deskriptif kualitatif digunakan untuk menganalisis kepraktisan LKS yang diperoleh berdasarkan oberservasi dan temuan pada pembelajaran small group, mengetahui letak kesulitan siswa dalam memahami arahan maupun petunjuk yang terdapat dalam LKS, dan mengetahui efektivitas dari LKS yang dikembangkan. Analisis deskriptif kuantitatif untuk menganalisis data yang berasal dari rata-rata latihan soal, rata-rata nilai ujian kompetensi, dan nilai ulangan harian. Data-data tersebut diolah untuk mengetahui kategori hasil belajar siswa. Kemudian untuk menentukan kategori ketuntasan penilaian tes hasil belajar dengan $\mathrm{KKM} \geq 80$.

\section{HASIL DAN PEMBAHASAN}

Pengembangan LKS ini meliputi dua tahap, yaitu preliminary study (tahap persiapan dan tahap pendesainan materi) dan formative evaluation (tahap evaluasi dan revisi). Tahap persiapan meliputi studi literatur, analisis kurikulum, analisis sumber belajar, dan pemilihan atau 
penentuan LKS. Tahap pendesainan materi menghasilkan LKS yang sesuai dengan prinsip-prinsip pembelajaran dan mencakup diantaranya : 1) petunjuk belajar, 2) kompetensi yang akan dicapai, 3) content atau isi materi pembelajaran, 4) informasi pendukung, 5) latihanlatihan, 6) petunjuk kerja, dan 7) evaluasi.
Formative Evaluation meliputi tahap self evaluation, expert review, one to one, revisi, small group, revisi, field test. Berikut ini merupakan cuplikan komentar atau saran yang diberikan validator pada tahap uji pakar seperti terlihat pada Tabel 1 berikut ini.

Tabel 1

Komentar atau Saran Validator/Expert

\begin{tabular}{cl}
\hline Nama Expert & \multicolumn{1}{c}{ Saran/Komentar } \\
\hline Misdalina, M.Pd. & 1. LKS belum menunjukkan berbasis CTL. \\
& Seharusnya siswa hanya diberi petunjuk dalam \\
& menemukan penyelesaian masalah. \\
& 2. LKS terlalu padat, pecah menjadi 4 LKS \\
3. Dari petunjuk-petunjuk itu siswa mampu & mengkonstruk konsepnya sendiri. \\
& 4. Komponen yang terkandung dalam CTL harus \\
& jelas ada pada tiap LKS yang disusun. \\
\hline Cik Ayu, S.Pd. & 5. LS sudah cukup bagus, tetapi gunakan bahasa \\
& yang lebih mudah dipahami siswa. \\
6. Gunakan bahasa yang jelas untuk memberikan \\
siswa petunjuk menemukan konsep sendiri. \\
7. Cari gambar dan masalah yang lebih dekat \\
dengan siswa.
\end{tabular}

Setelah tahap expert, evaluasi dilanjutkan pada tahap one-to-one. Pada tahap one-to-one, LKS diberikan kepada dua orang siswa kelas IX. Setelah itu, diperoleh 4 LKS yang valid. Evaluasi selanjutnya dilakukan pada tahap small group. LKS diberikan pada enam orang siswa kelas IX. LKS yang dikembangkan setelah melalui tahap uji pakar, one to one, small group menghasilkan prototipe kedua, kemudian prototipe kedua direvisi dengan perubahan seperti tampak pada Tabel 2.
Prototipe ketiga yang dihasilkan, kemudian diujicobakan pada siswa yang menjadi subjek penelitian, yaitu siswa kelas VIII salah satu SMP negeri di Palembang sebanyak 38 orang siswa, tahap ini disebut field test. Dalam penelitian pengembangan LKS, indikator untuk menyatakan LKS dikatakan efektif, misalnya dilihat dari komponenkomponen : 1) hasil belajar peserta didik, 2) aktivitas peserta didik, dan 3) respon peserta didik. Komponen efektifitas yang diamati oleh peneliti untuk melihat efek potensial yaitu: 1) 
aktivitas pembelajaran siswa selama uji coba, dan 2) hasil jawaban siswa yang dinyatakan dengan kriteria tertentu.

Tabel 2

\section{Perbandingan Revisi Prototype Kedua}

\begin{tabular}{ll}
\hline Sebelum Revisi & Setelah Revisi \\
\hline Terdapat titik-titik sebagai tempat siswa & Hanya space kosong dan siswa cukup \\
menjawab pertanyaan/stimulus. & $\begin{array}{l}\text { diberikan intervensi berupa } \\
\text { pertanyaan. }\end{array}$ \\
\hline Diberikan gambar satu buah contoh & Hanya diberikan kotak tempat siswa \\
kerangka prisma. & menggambar dari praktek \\
& menggunting kotak/model prisma dan \\
& limas yang diberikan \\
\hline
\end{tabular}

Selama proses pembelajaran siswa langsung berinteraksi dengan LKS Berbasis CTL sementara guru bertindak sebagai fasilitator, aktivitas pembelajaran seperti tampak pada Gambar 1.

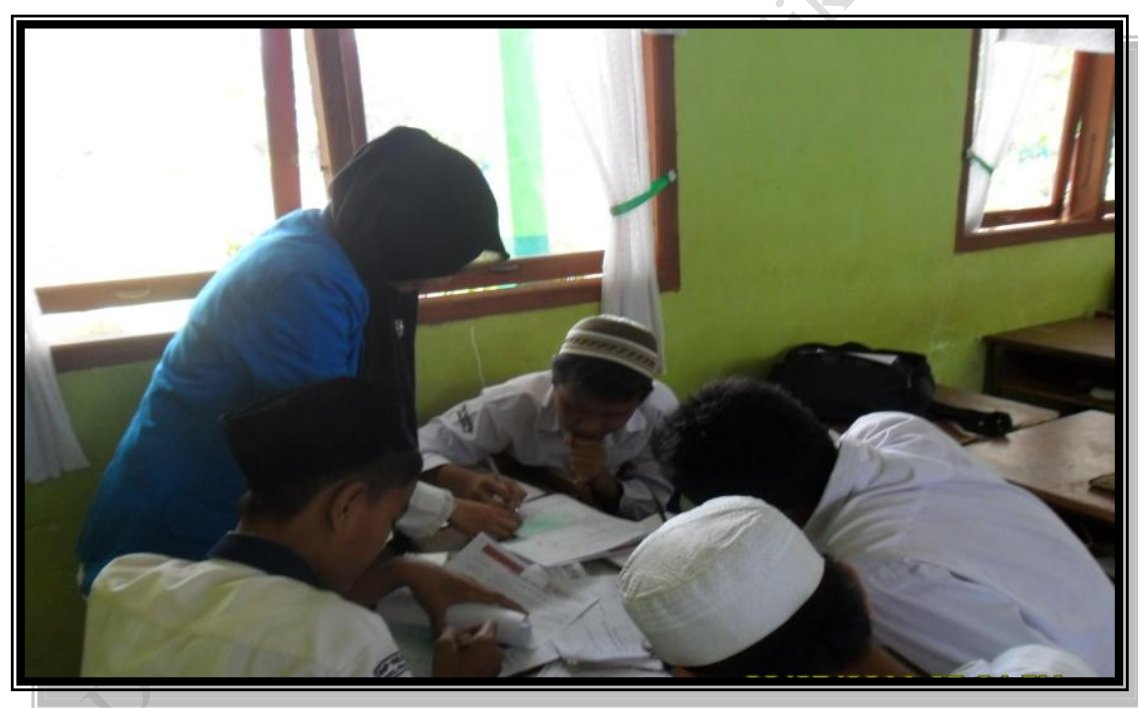

Gambar 1

Aktivitas Pembelajaran

Kegiatan siswa selama penelitian tergolong aktif hal tersebut terjadi karena tingkat kejenuhan siswa berkurang. Hal ini seiring dengan pendapat Muslich (2007:42) yang menyatakan bahwa pembelajaran yang berbasis CTL akan menjadikan siswa aktif, kreatif, produktif, dan mementingkan kerja sama sehingga memberikan pengalaman yang bermakna bagi siswa. Selama ini siswa belajar dengan sistem yang monoton di mana guru sebagai pusatnya sedangkan siswa hanya sebagai penerima yang pasif. Dengan pembelajaran menggunakan LKS berbasis CTL, siswa mendapatkan pengalaman baru yang belum pernah mereka dapatkan dari guru. Siswa dituntut aktif dan menemukan sendiri 
pengetahuan serta belajar dengan benda-benda yang ada di kehidupan sehari-hari mereka sehingga ingatan siswa lebih kuat dan aktivitas dalam proses pembelajaran lebih tinggi.

$$
\text { Pada akhir pertemuan }
$$
pembelajaran menggunakan LKS Berbasis CTL pada tahap field test, siswa diberi latihan sesuai materi untuk melihat efek potensial siswa terhadap tes akhir belajar. Pada latihan tersebut, peneliti dapat melihat kemampuan siswa dalam mengerjakan LKS dan akan berefek terhadap hasil belajar. Hal ini dapat terlihat dari hasil belajar siswa materi prisma dan limas yang dilakukan pada pertemuan terakhir pembelajaran. Sebagian besar siswa sudah mampu menyelesaikan soal.

Penelitian ini menghasilkan 4 LKS Berbasis CTL dengan juduljudul pada Gambar 2.

Tabel 3

Data Tes Hasil Belajar

\begin{tabular}{lll}
\hline Tingkat Ketuntasan & Banyak Siswa & Presentase \\
\hline Tidak Tuntas & 4 & $10,5 \%$ \\
\hline Tuntas & 34 & $89,5 \%$ \\
\hline Jumlah & 38 & $100 \%$ \\
\hline
\end{tabular}

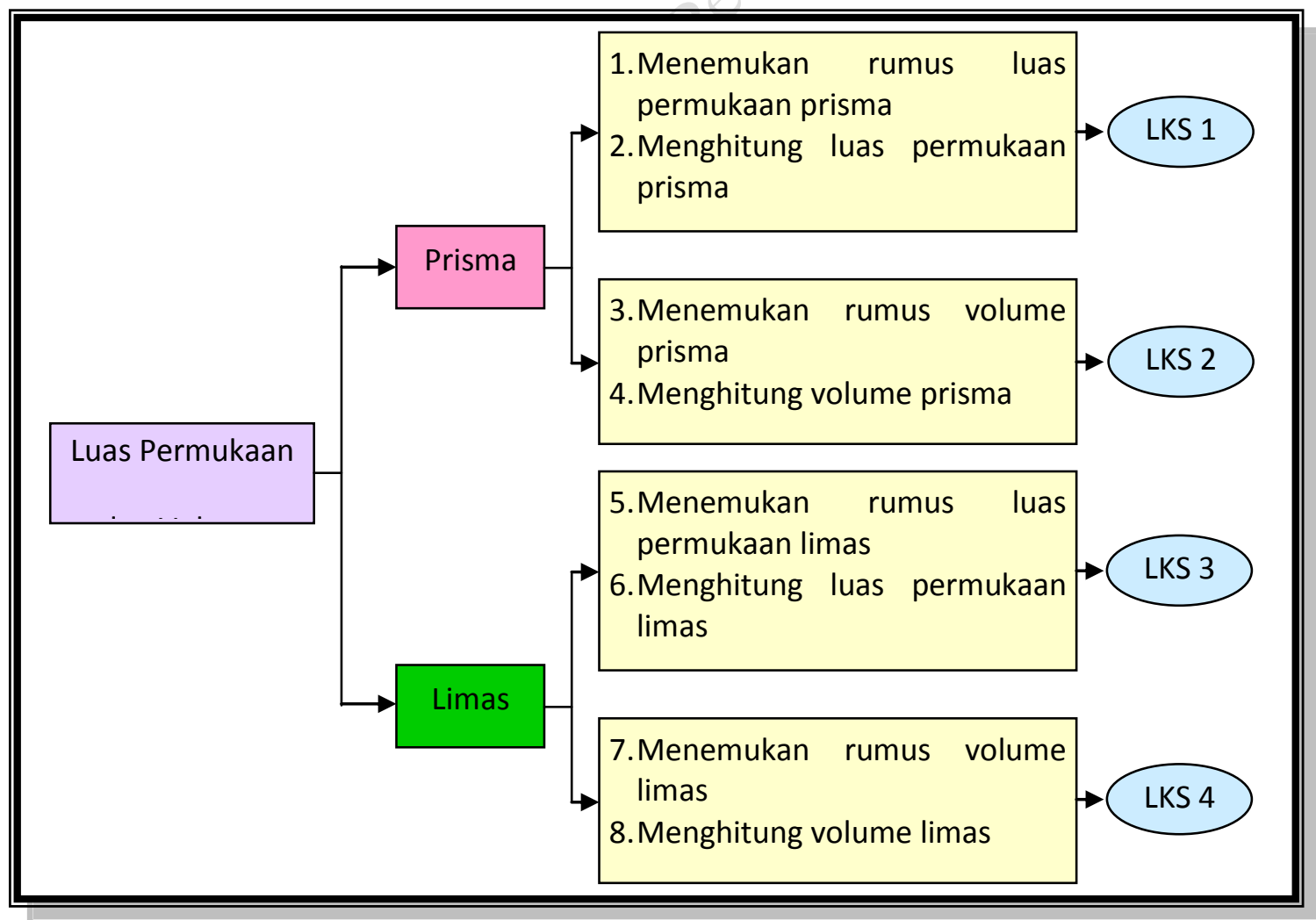

Gambar 2

Judul-judul LKS Berbasis CTL 
SIMPULAN DAN SARAN

Penelitian ini telah menghasilkan suatu produk berupa LKS Berbasis Pendekatan CTL materi prisma dan limas. Berdasarkan hasil penelitian dan pembahasan diperoleh kesimpulan:

1. Karakteristik LKS Berbasis Pendekatan CTL materi prisma dan limas yang valid dan praktis adalah sebagai berikut:

a. Kelayakan isi LKS disesuaikan dengan SK, KD, dan tujuan pembelajaran kurikulum (materi prisma dan limas terkait luas permukaan dan volume). LKS menggunakan bahasa yang jelas dan tidak ambigu. Ilustrasi grafis, gambar, dan model ditampilkan dan digunakan untuk mendukung penjelasan materi dalam LKS.

b. Selama siswa menggunakan LKS dalam proses pembelajaran, siswa tidak menemui kesulitan yang berarti, sehingga bisa mengkombinasikan

pemanfaatan LKS Berbasis

Pendekatan CTL dalam mempelajari dan menyelesaikan permasalahan yang berkaitan dengan materi prisma dan limas.

2. Berdasarkan proses pengembangan diperoleh bahwa prototype LKS yang dikembangkan telah memiliki efek potensial, hal ini terlihat saat siswa mampu : 1) menemukan rumus luas permukaan dan volume prisma serta menghitungnya; 2) menemukan rumus luas permukaan dan volume limas serta menghitungnya.

Adapun beberapa saran dari peneliti terhadap penelitian ini adalah sebgai berikut.

1. Guru diharapkan dapat menggunakan LKS Berbasis CTL untuk materi prisma dan limas.

2. Calon peneliti diharapkan dapat melakukan penelitian sejenis dengan pokok bahasan yang lain dengan memperhatikan kelemahan yang ada dalam penelitian ini.

\section{DAFTAR PUSTAKA}

Akker, J. v.d. (1999). Principles and Methods of Development Research. Dalam J.v.d Akker (Ed). Design Approaches and Tools in Education and Training. Dordrecht: Kluwer Academic Publishers.

BSNP. (2006). Panduan Penyusunan Kurikulum Tingkat Satuan Pendidikan Jenjang Pendidikan Dasar dan Menengah. Jakarta: BSNP.

Dahar, R.W. (1996). Teori-Teori Belajar. Jakarta: Erlangga

Dirjen Dikdasmen. (2004). ModelModel Pembelajaran

Matematika. Jakarta: Depdiknas.

Dirjen Dikdasmen. (2004). Pendekatan Pembelajaran Matematika. Jakarta: Depdiknas.

Hadi, S. (2002). Effective Teacher Profesional Development for The Implementation of Realistic Mathematics Education in Indonesia. Disertasi Doctor. Ecschede: University of Twente. 
Inra. (2010). Pedoman Umum Pengambangan Bahan Ajar. Bandung: Alfabeta.

Johnson, Elaine B. (2006). Contextual Teaching and Learning. Bandung: MLC.

Lestari, Linda Puji. (2006). Keefektifan Pembelajaran dengan Penggunaan Alat Peraga dan Lembar Kerja Siswa (LKS) Terhadap Hasil Belajar Matematika dalam Pokok Bahasan Bangun Segiempat Pada Siswa Kelas VII Semester 2 di SMP Muhammadiyah Margasari Kabupaten Tegal Tahun Pelajaran 2005/2006. Skripsi S1 (belum diterbitkan). Semarang: Jurusan Matematika FMIPA UNNES (http://digilib.unnes.ac.id/gsdl/c ollect/skripsi/archives/HASH01 c2/691a32d6.dir/doc.pdf, diakses 11 Desember 2010)

Mulyana, T. (2008). Pembelajaran Analitik Sintetik untuk Meningkatkan Kemampuan Berpikir Kritis dan Kreatif Matematik Siswa Sekolah Menengah Atas. Disertasi pada Program Studi Pendidikan Matematika Sekolah Pasca sarjana UPI. Bandung: Tidak diterbitkan.

Muslich, Masnur. (2007). KTSP Pembelajaran Berbasis Kompetensi dan Kontekstual. Jakarta: Bumi Aksara.
Riyanto, Yatim. (2010). Paradigma Baru Pembelajaran. Jakarta: Kencana.

Shoimin, A. (2014). 68 Model Pembelajaran Inovatif dalam Kurikulum 2013. Jakarta: Arruzz Media.

Suryadi, D. (2010). "Metapedadidaktik dan Didactical Design Research (DDR): Sintesis Hasil Pemikiran Berdasarkan Lesson Study", dalam Teori, Paradigma, Prinsip, dan Pendekatan Pembelajaran MIPA dalam Konteks Indonesia. Bandung: FPMIPA UPI.

Tessmer, M. (1993). Planning and Conducting Formative Evaluation. London: Kogan Page.

Trianto. 2007. Model-Model Pembelajaran Inovatif Berorientasi Konstruktivistik. Jakarta: Prestasi Pustaka.

Turmudi. (2010). "Pembelajaran Matematika Kini dan Kecenderungan Masa Mendatang dalam Teori, Padigma, Prinsip, dan Pendekatan Pembelajaran MIPA", dalam Konteks Indonesia. Bandung: FPMIPA UPI.

Widiyanto, A. (2007). Isi LKS Berbasais Web. [Online]. Tersedia: http://ahliswiwite.wordpress.co m/isi-lks-berbasis-web.doc. [5 Maret 2013] 